\title{
RIMA-Tuna: A Supply Chain Risk Management Tool for Tuna
}

\author{
Putu Dana Karningsih ${ }^{1, a, *}$, Dewanti Anggrahini ${ }^{1}$, Nani Kurniati ${ }^{1}$, Mokh Suef ${ }^{1}$, Olivia Pradany \\ Panjaitan $^{1}$, Nur Syahroni ${ }^{2}$ \\ ${ }^{1}$ Department of Industrial Engineering, Institut Teknologi Sepuluh Nopember, Surabaya, Indonesia \\ ${ }^{2}$ Department of Ocean Engineering, Institut Teknologi Sepuluh Nopember, Surabaya, Indonesia \\ a.dana@ie.its.ac.id \\ *corresponding author
}

Keywords: Supply Chain Risk Management, Risk Interrelationships, House of Risk, Supply Chain Risk Identification System

Abstract: With approximately $81 \%$ of Indonesia area is ocean, Indonesian government sees that the future of Indonesian civilization depends heavily on proper maritime management. Thus, for 2015-2019 period, Indonesian Ministry of Marine Affairs and Fisheries (MMAF) plans to manage Indonesian maritime and fisheries in a way so that sovereignty, sustainability and prosperity for its people can be achieved. Fisheries sector contribution to Indonesia GDP shows a growing trend. MMAF sets target that GDP of fisheries sector should rise to $12 \%$ in 2019. Tuna is selected by MMAF as one of top marine commodity besides shrimps/prawns, seaweeds, and crabs since Indonesia is one of the largest Tuna producer. However, the sustainability of tuna catches is in alarming conditions especially Yellow fin and Southern Bluefin. Therefore, MMAF should have a proper strategy that could encourage Indonesian tuna competitiveness so it would enhance Indonesian fisheries GDP as well as maintaining its sustainability. In order to develop an effective strategy, potential risks of Indonesian Tuna supply chain should be identified including its interrelationships. This research proposes a framework for managing supply chain risks of Tuna. The framework of Supply Chain Risk Identification, Mapping and Assessment for Tuna (RIMA-Tuna) is started from Tuna supply chain risks identification, risks interrelationships mapping, and finally recommendation of risk treatments. RIMA-Tuna is developed by integrating and modifying Supply Chain Risk Identification System framework with House of Risk. RIMA-Tuna does not only identify, assess, and evaluate most of potential risks in Tuna supply chain, but also interrelationships between risks can be mapped so it would lead to a more effective risk treatment strategy and a better Indonesian Tuna management.

\section{Introduction}

More than two thirds of Indonesia area is ocean including its Exclusive Economic Zone [1]. Indonesian Ministry of Marine Affairs and Fisheries (MMAF) have a plan to manage Indonesian maritime and fisheries to ensure sovereignty, sustainability and prosperity for Indonesian people. 
There is a positive trend of Fisheries sector contribution to Indonesia GDP. From 2014 to 2015 GDP of fisheries sector increases from 7.3\% to 8.3\% and it is almost double than National GDP. In 2019, MMAF aims that GDP of fisheries sector can be increased to $12 \%$. One of the world's popular fish is Tuna. As Indonesia is the largest Tuna producer in the world, thus MMAF selects Tuna as one of top marine commodity besides shrimps/prawns, seaweeds, and crabs. In 2015 the value of export of Indonesian Tuna is 584 million US dollars. Yellow fin, Skipjack (Cakalang), Albacore, Bigeye, and Southern Bluefin are example of tuna types that normally available in Indonesian sea. Mostly Indonesian tuna is caught in Western Central Pacific Ocean and Indian Ocean area. However, there is a problem in Indonesian tuna sustainability. In 2017, Yellow fin and Southern Bluefin are already over fished in Indian Ocean. While other types of Tuna are still in moderately full exploited in both oceans. Thus, on one hand, MMAF should provide program to optimize Indonesian tuna catches which could raise its contribution to Indonesian GDP. On the other hand, MMAF should also ensures sustainability of Indonesia Tuna. Complexity to manage Tuna catches is not only on trade-off between sustainability and competitive, but also due so many factors should be considered. Development of an effective Tuna management strategy requires understanding of potential risks of Indonesian Tuna supply chain and its interrelationships, since Tuna industry consists of many players (ea. fishermen, trader, processing companies and many more) and it is highly susceptible to external environment (ea. weather, sea temperature, etc). This research objective is to propose a comprehensive framework to manage supply chain risks of Tuna. This framework is called Supply Chain Risk Identification, Mapping and Assessment for Tuna (RIMA-Tuna). It encompasses from Tuna supply chain risks identification, risks interrelationships mapping, risks assessments and finally suggestion on risk treatments. RIMA-Tuna is developed by integrating two tools from previous research, they are: Supply Chain Risk Identification System (SCRIS) framework [2] and House of Risk (HOR) [3].

This paper is divided into five sections, the literature study on supply chain risk management and its supporting tools is described in section 2 and 3. The development of SCRM framework specifically for Tuna is elaborated in section 4. Finally, section 5 presents conclusion and future works of this research.

\section{Supply Chain Risk Management}

Supply chain risk is "anything that disrupts or impedes the information, material or product flows from original suppliers to the delivery of the final product to the ultimate end user"[4]. Managing supply chain (SC) risk is very essential especially nowadays. Complexity of today businesses such as overseas suppliers (sourcing), intercontinental distributions, global competition, and many more has led to highly intertwined and interdependent supply network. Each supply chain player is susceptible to uncertainty and disruptions that are originated from internal or external supply chain. In general, internal SC consists of focal organization, its suppliers and customers including logistic providers, supplier's suppliers, retailers and distributors. External SC is external factors/actors that relates with SC operations such as economic stability, government policy, manmade and natural disaster [5]. Consequently, any disturbances that initiated from internal and/or external of supply chain may affect its ability to provide product and service to its customer at the right time, location, quality, quantity and cost.

According to [5] and [6], Supply Chain Risk Management (SCRM) can be defined as a coordinated endeavour of supply chain members to collaboratively minimize supply chain vulnerability by identifying, evaluating, mitigating and monitoring unexpected events within the supply chain and external to it. When SC risks is managed properly, it would lead to a higher competitiveness of the whole supply network. Conversely, it could lead to financial losses or closing down the businesses when SC risks are not well managed 
SCRM consists of several steps, they are: (1) Identify risk is to determine potential SC risks and their sources, (2) Assess risk is to measure the magnitude of SC risks, (3) Evaluate risk is to prioritize SC risks according to certain criteria, and (4) Mitigate risk is to formulate action to deal with SC risks (i.e. avoid, reduce, transfer, or accept). In order to formulate an effective and suitable risk mitigation, most of SC risks should not only to be identified, but also their interrelationships should be known and considered [2].

\section{Supply Chain Risk Management Tools}

There are some approaches/tools that could be utilized for supporting each step of supply chain risk management process. Risk identification is the first step on SCRM. To identify risk is not an easy task since most of (if not all) risks should be able to be recognized. Therefore, some tools are needed to assist top management in managing SC risks. Brainstorming, interviews, questionnaires, scenario analysis, check list and flow chart are example of several approaches for risk identification that has been applied widely [7][8][9]. Influence diagram is also a tool for identifying risks as well as mapping them including theirs interrelationships [10], [11]. Similarly, a study by [2] propose a knowledge based system for Supply Chain Risk Identification System (SCRIS) as a tool for identifying and classifying SC risks according to five business processes of SCOR (i.e. Plan, Source, Make, Deliver and Return). Furthermore, SCRIS also accommodates relationships between risks with its risk factor (cause of risk) and also interrelationships between risks or risk factors and they are represented by hierarchical and causal structure.

Next, the second step of SCRM is to assess risks. Structured interview, expert judgment, event tree, fault tree, statistical and numerical analysis, simulation and computer modelling are utilized for measuring risk in qualitatively or quantitative manner [9]. Risk Matrix is a tool for assessing and also evaluating risks in the form of matrix (two-dimensional grid). This tool measures risks by multiplying likelihood and consequence then plot of them according to several level of risk magnitude (i.e. catastrophic, critical, marginal, and negligible) [12].

A more recent tool that could covers the whole steps of SCRM, from identifying to formulating and prioritizing mitigation strategy of SC risks is House of Risk (HOR) which is proposed in the study of [3] . House of Risk (HOR) is developed by integrating Failure Mode and Effect Analysis (FMEA) and House of Quality (HOQ) framework. HOR consist of two matrix, namely: HOR stage 1 and HOR stage 2 . HOR stage 1 aims to prioritize risk agents and then are analysed further in stage 2. Initially, it identifies risk events and risk agents (causes of risk event) and relations between risk event and risk agent. Risk events is generated according to five SCOR business processes, they are: Plan, Source, Make, Deliver and Return. Then, it prioritizes the most influential risk agents based on the rank of Aggregate Risk Potential (ARP) value which is calculated by multiplying severity level of risk event with occurrence level of risk agent and correlation level of risk event with risk agent. HOR stage 2 aims to support decision maker to choose the most effective proactive actions (mitigation strategy) according to Effectiveness to Difficulty Ratio for the selected risk agents accordingly. HOR has been utilized in several studies such as in [13], [14], [15] and [16].

Even though, House of Risk could encompasses the whole steps of SCRM, it only considers relations between risk events and risk agents. While, the interrelationships of SC risk could also occurred between risk events and between risk agents. Moreover, these interrelations could also happened across different SC business process stages. For example, SC risk that is occurred in Make stage could be originated from risk in Source stage, and so on. Therefore, there is a need to develop a framework for SCRM tool that is able to consider complex interrelationships between SC risks and covers entire steps of SCRM. This framework is proposed in this study by combining SC risks structure of SCRIS with House of Risk. 


\section{Development of RIMA-Tuna}

A specific framework of Supply Chain Risk Identification, Mapping and Assessment for Tuna (RIMA-Tuna) is developed to response two issues, they are: (1) a comprehensive tool that covers all stages of SCRM while considers interrelationships between risks, and (2) a specific tool for managing $\mathrm{SC}$ risk for Tuna.

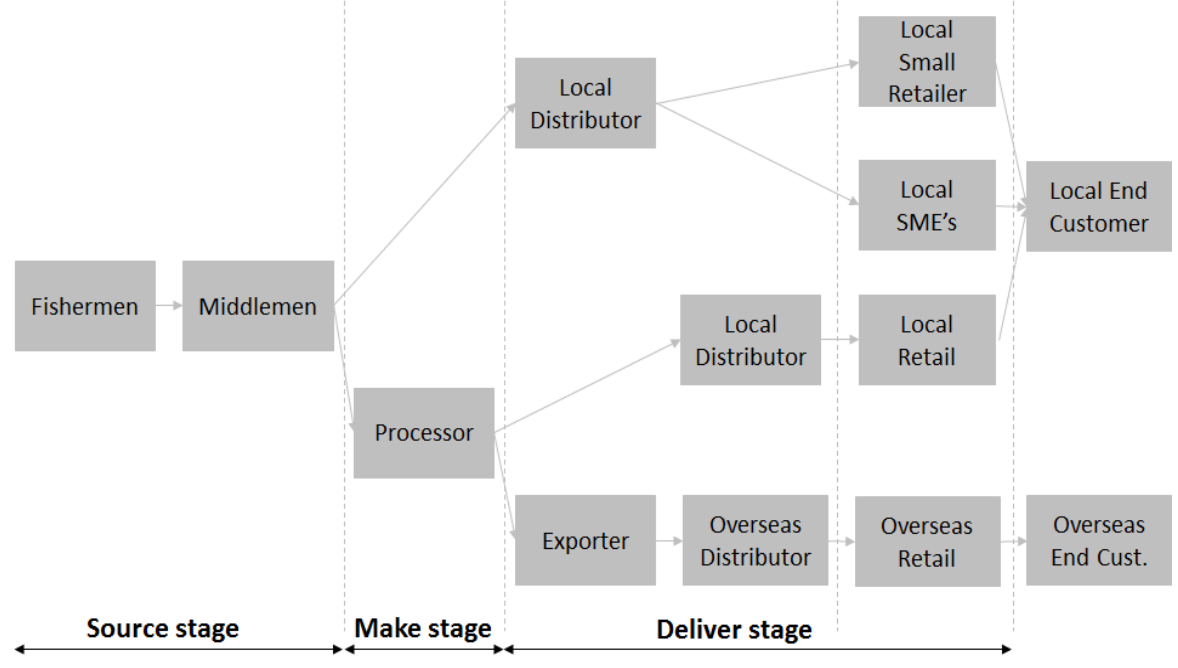

Figure 1: Generic Supply Chain of Tuna.

To begin with, risks of Tuna SC is identified and arranged based on hierarchical and causal structure that is modified from structure of SCRIS. While, SCRIS using five stages of SC activities (i.e. Plan, Source, Make, Deliver and Return), RIMA-Tuna utilizes Source, Make and Deliver operations, which is in the same terminology as SCOR. However, it represents specific operations on Supply Chain Tuna as can be seen in Figure 1, so it conveys different definition. In this research, supply chain Tuna consists of four activities, namely: fishing, trading, processing and distribution [16]. These four activites are then categorized into three main operations, they are:

- Fishing and trading, which is categorized as Source

- Processing, which is categorized as Make

- Distributions, which is categorized as Deliver.

Thus, this classification become the first level on hierarchical structure. Next, the second level consists of internal Tuna SC (direct) players and external environment of Tuna SC. Thus, at Source operation that consists of fishing and trading, the SC players are fishermen and traders. At Make operations, the only SC player is processors which is industry that process fresh tuna into tuna by product (ea. loins, smoked/salted, can tuna). While, Deliver operations consist of four players, they are: distributors, transport firms (third party logistics), retailers and customers. External environment consists of similar factors as is in SCRIS with two additional actors (i.e. Tuna International Trade Market, Government/MMAF) and omits "Complementary product organisation". Then, the causal structure is located under each level 2 of hierarchical structure. RIMA-Tuna also use similar arrangement as is in SCRIS but only take into account risk events and risk agents/factors. Five why's analysis is utilized to determine risk agents (factors) which is the root cause of risk events. After potential risk events and risk agent are plotted using combination of hierarchical and causal structure, the interrelationships between risk events and between risk agents is developed and represented by using arrows. Figure 2 shows RIMA-Tuna risk identification and mapping structure. 


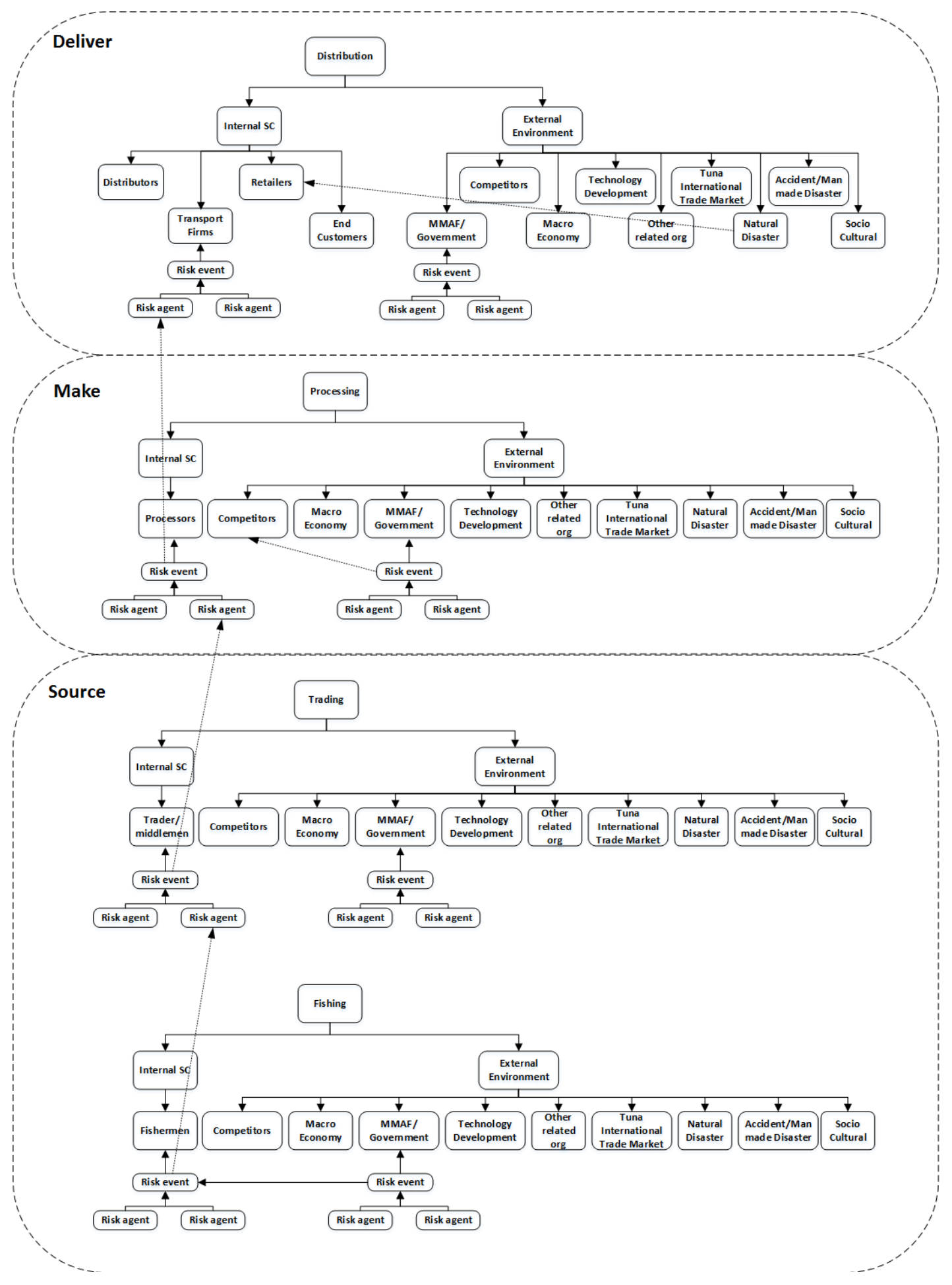

Figure 2: RIMA-Tuna Risk Identification and Mapping Structure.

Secondly, House of Risk is modified to assess and formulate mitigation/proactive actions for SC risk of Tuna that have been identified and mapped previously. On the RIMA-Tuna, at HOR stage 1, risk events are divided into risks that are occurred at Source, Make and Deliver operations. Therefore there are three matrix of HOR stage 1 (Figure 3). There are two reasons why using different HOR stage 1 matrix for Source, Make and Deliver. First, as different operations have different internal SC 
players, to determine occurrence and severity level of each stage should be conducted by the main SC player/actor of that operations/activities accordingly. Second, to recognize that every operations has its own priority of risk agents that should be considered in HOR stage 2 . However, all prioritized risk agent from three matrix of HOR stage 1 are then combined together and further analysed on one HOR stage 2 matrix. Interrelationships between risk events or between risk agents that has been identified previously is then take into account on this matrix when formulating proactive actions. For example, a risk event (i.e. E1) at Make operations is occurred due to one risk agent (i.e. A1) also at Make operations. If the root cause of this risk agent (A1) is actually originated from three risk agents (i.e. A2, A3, and A4) at Source operations, thus when formulating of proactive action for risk agent $\mathrm{A} 1$, risk agent $\mathrm{A} 2, \mathrm{~A} 3$ and $\mathrm{A} 4$ should also considered. Therefore, proactive action become more effective as the root cause of risk is recognized and considered. RIMA-Tuna also use "proactive action" terminology to replace "mitigation strategy" in order to encompass different treatment such as avoid, reduce, transfer and accept the risk agents.

\begin{tabular}{|c|c|c|c|c|c|c|c|}
\hline $\begin{array}{c}\text { Source } \\
\text { (Fishing and Trading) }\end{array}$ & \multicolumn{6}{|c|}{$\operatorname{RiskAgent}\left(\mathrm{A}_{\mathrm{j}}\right)$} & $\begin{array}{l}\text { Severity of } \\
\text { risk Event }\end{array}$ \\
\hline RiskEvent $\left(\mathrm{E}_{\mathrm{i}}\right)$ & $A_{3}$ & As & \multirow[t]{3}{*}{ As } & \multirow[t]{3}{*}{$A_{4}$} & \multirow{3}{*}{$\begin{array}{l}\ldots \\
\ldots \\
\ldots \\
\end{array}$} & \multirow{3}{*}{$\begin{array}{l}A_{j} \\
R_{1 j} \\
R_{2 j} \\
\end{array}$} & \\
\hline $\mathrm{E}_{1}$ & $R_{11}$ & & & & & & $\mathrm{SV}_{1}$ \\
\hline$E_{2}$ & $R_{12}$ & $R_{22}$ & & & & & $\mathrm{SV}_{2}$ \\
\hline$\ldots$ & $\ldots$ & $\ldots$ & $\cdots$ & $\ldots$ & $\ldots$ & $\ldots$ & $\ldots$ \\
\hline$E_{i}$ & $\mathrm{R}_{i 1}$ & $R_{: 2}$ & $R_{i 3}$ & $R_{i 4}$ & $\ldots$ & $R_{i j}$ & $\mathrm{SV}_{\mathrm{i}}$ \\
\hline Occurrence of risk agent $\left(\mathrm{O}_{j}\right)$ & $\mathrm{O}_{1}$ & $\mathrm{O}_{2}$ & $\mathrm{O}_{3}$ & $\mathrm{O}_{4}$ & $\cdots$ & $\mathrm{O}_{\mathrm{j}}$ & \\
\hline Aggregate Risk Potential & $A R P_{1}$ & $\mathrm{ARP}_{2}$ & $\mathrm{ARP}_{3}$ & $\mathrm{ARP}_{4}$ & $\ldots$ & $A R P_{j}$ & \\
\hline $\begin{array}{c}\text { Make } \\
\text { (Processing) }\end{array}$ & \multicolumn{6}{|c|}{$\operatorname{Risk} A g \operatorname{sen}\left(\mathrm{A}_{\mathrm{j}}\right)$} & $\begin{array}{l}\text { Severity of } \\
\text { risk Event }\end{array}$ \\
\hline RiskEvent $\left(\mathrm{E}_{\mathrm{i}}\right)$ & $A_{1}$ & As & As & $A_{4}$ & $\ldots$ & $A_{j}$ & \\
\hline$E_{1}$ & $R_{11}$ & \multirow[b]{2}{*}{$R_{22}$} & & & \multirow{2}{*}{$\begin{array}{l}\ldots \\
\ldots \\
\ldots\end{array}$} & $R_{1 j}$ & $\mathrm{SV}_{1}$ \\
\hline $\mathrm{E}_{2}$ & $R_{12}$ & & & & & $R_{2 j}$ & $\mathrm{SV}_{2}$ \\
\hline$\cdots$ & $\ldots$ & $\ldots$ & $\ldots$ & $\ldots$ & $\cdots$ & $\ldots$ & $\ldots$ \\
\hline$E_{i}$ & $R_{i 1}$ & $R_{12}$ & $R_{i 3}$ & $R_{j 4}$ & $\ldots$ & $R_{i j}$ & $\mathrm{SV}_{\mathrm{i}}$ \\
\hline Occurrence of risk agent $\left(\mathrm{O}_{j}\right)$ & $\mathrm{O}_{1}$ & $\mathrm{O}_{2}$ & $\mathrm{O}_{3}$ & $\mathrm{O}_{4}$ & $\ldots$ & $\mathrm{O}_{\mathrm{j}}$ & \\
\hline Aggregate Risk Potential & $A R P_{1}$ & $\mathrm{ARP}_{2}$ & $\mathrm{ARP}_{3}$ & $\mathrm{ARP}_{4}$ & $\ldots$ & $A R P_{j}$ & \\
\hline \multirow{2}{*}{$\begin{array}{c}\text { Deliver } \\
\text { RiskEvent }\left(\mathrm{E}_{\mathrm{i}}\right)\end{array}$} & \multicolumn{6}{|c|}{$\operatorname{Risk} A g \operatorname{gnt}\left(\mathrm{A}_{i}\right)$} & $\begin{array}{l}\text { Severity of } \\
\text { risk Event }\end{array}$ \\
\hline & $A_{1}$ & $A_{2}$ & As & $A_{4}$ & $\ldots$ & $A_{j}$ & \\
\hline $\mathrm{E}_{1}$ & $\mathrm{R}_{11}$ & & & & $\ldots$ & $R_{1 j}$ & $\mathrm{SV}_{1}$ \\
\hline$E_{2}$ & $\mathrm{R}_{12}$ & $R_{22}$ & & & $\cdots$ & $R_{2 j}$ & $\mathrm{SV}_{2}$ \\
\hline$\ldots$ & $\ldots$ & $\ldots$ & $\ldots$ & $\ldots$ & $\ldots$ & $\ldots$ & $\ldots$ \\
\hline$E_{i}$ & $\mathrm{R}_{\mathrm{i1}}$ & $\mathrm{R}_{22}$ & $R_{i 3}$ & $\mathrm{R}_{\mathrm{i}}$ & $\ldots$ & $R_{\mathrm{ij}}$ & $\mathrm{SV}_{\mathrm{i}}$ \\
\hline Occurrence of risk agent $\left(\mathrm{O}_{j}\right)$ & $\mathrm{O}_{1}$ & $\mathrm{O}_{2}$ & $\mathrm{O}_{3}$ & $\mathrm{O}_{4}$ & $\ldots$ & $\mathrm{O}_{\mathrm{j}}$ & \\
\hline Aggregate Risk Potential ${ }_{\mathrm{j}}$ & $A R P_{1}$ & $\mathrm{ARP}_{2}$ & $\mathrm{ARP}_{3}$ & $\mathrm{ARP}_{4}$ & $\ldots$ & $A R P_{j}$ & \\
\hline
\end{tabular}

Figure 3: Modification of HOR Stage 1 Matrix.

\section{Conclusion and Future Works}

This study elaborates development RIMA-Tuna, a tool for Supply Chain Risk Identification, Mapping and Assessment for Tuna. This tools is develop by integrated risk identification structure of Supply Chain Risk Identification Systems (SCRIS) and House of Risk (HOR). Some modification is made to consider specific characteristics of Tuna SC activities they are: Source operations (fishing and trading activity), Make operations (processing activity) and Deliver operations (distribution activity). For the future works, RIMA-Tuna is applied to a case study of Indonesian Tuna Supply Chain specifically in Indian Ocean. Furthermore, there is an opportunity to integrate with a quantitative tool for determine interrelationships between risks (ea. Interpretive Structural Modelling). 


\section{Acknowledgement}

This study is funded by Lembaga Penelitian dan Pengabdian kepada Masyarakat (LPPM) and Pusat Studi Kelautan - Institut Teknologi Sepuluh Nopember (ITS) Surabaya Indonesia.

\section{References}

[1] Asian Development Bank, Indonesia country water assessment. 2016.

[2] B. Kayis and P. Dana Karningsih, "SCRIS: A knowledge-based system tool for assisting manufacturing organizations in identifying supply chain risks, " J. Manuf. Technol. Manag., vol. 23, no. 7, pp. 834-852, 2012.

[3] I. Nyoman Pujawan and L. H. Geraldin, "House of risk: a model for proactive supply chain risk management," Bus. Process Manag. J., vol. 15, no. 6, pp. 953-967, 2009.

[4] H. Peck, "Reconciling supply chain vulnerability, risk and supply chain management," J. Int. J. Logist. Res. Appl., vol. 9, no. 2, pp. 127-142, 2006.

[5] P. Chapman, M. Christopher, U. Jüttner, H. Peck, and R. Wilding, "Identifying and Managing Supply Chain Vulnerability,” Logist. Transp. Focus, vol. 4, no. 4, pp. 59-70, 2002.

[6] W. Ho, T. Zheng, H. Yildiz, and S. Talluri, "Supply chain risk management: a literature review, " Int. J. Prod. Res., vol. 53, no. 16, pp. 5031-5069, 2015.

[7] C. Chapman, "Key points of contention in framing assumptions for risk and uncertainty management," Int. J. Proj. Manag., vol. 24, no. 4, pp. 303-313, 2006.

[8] CIPS, "Supply Chain Vulnerability," 2002.

[9] A. Ahmed, B. Kayis, and S. Amornsawadwatana, "A review of techniques for risk management in projects," Benchmarking an Int. J., vol. 14, no. 1, pp. 22-36, 2007.

[10] J. Hallikas, I. Karvonen, U. Pulkkinen, V. M. Virolainen, and M. Tuominen, "Risk management processes in supplier networks,” Int. J. Prod. Econ., vol. 90, no. 1, pp. 47-58, 2004.

[11] L. a. Deleris and F. Erhun, "Risk management in supply networks using Monte-Carlo simulation," Proc. Winter Simul. Conf. 2005, pp. 1643-1649, 2005.

[12] S. L. Murray, K. Grantham, and S. B. Damle, "Development of a Generic Risk Matrix to Manage Project Risks," J. Ind. Syst. Eng., vol. 5, no. 1, pp. 35-51, 2011.

[13] W. Widiasih, P. D. Karningsih, and U. Ciptomulyono, "Development of Integrated Model for Managing Risk in Lean Manufacturing Implementation: A Case Study in an Indonesian Manufacturing Company, ” Procedia Manuf., vol. 4, no. Lm, pp. 282-290, 2015.

[14] D. S. Dewi, B. Syairudin, and E. N. Nikmah, "Risk Management in New Product Development Process for Fashion Industry: Case Study in Hijab Industry,” Procedia Manuf., vol. 4, no. Iess, pp. 383-391, 2015.

[15] C. Kasemset, J. Wannagoat, W. Wattanutchariya, and K. Y. Tippayawong, "A Risk Management Framework for New Product Development: A Case Study,” Ind. Eng. Manag. Syst., vol. 13, no. 2, pp. 203-209, 2014.

[16] S. M. Parenreng, "Model pengelolaan risiko supply chain mempertimbangkan kepentingan multistakeholder pada komoditas tuna," Institut Teknologi Sepuluh Nopember, 2016. 